\title{
ANTIGUA AND BARBUDA
}

Area: 442 sq. km

Population: 74,000

Capital: St John's

Governor-General: Sir Wilfred Ebenezer Jacobs

Antigua and Barbuda comprises three islands, Antigua, Barbuda and uninhabited Redonda. It became independent on 1 November 1981 as a constitutional monarchy, with the British Sovereign as its Head of State, represented by the Governor-General.

The Antigua Police is headed by a commissioner and is part of the Judicial and Legal Services Commission. The divisional headquarters is at St John's, and there are five sub-divisional headquarters at All Saints, Barbuda, Bolans, Parham, and St John's. Personnel strength is about 600. The police force is also in charge of the country's prison services. The Antigua Central Prison has accommodation for 120 male and 19 female prisoners, and there are separate installations for juveniles. 